\title{
STUDIES ON MICROBIAL DEGRADATION OF CEPHALOSPORIN C DERIVATIVES. I
}

THE ROLE OF $\beta$-LACTAMASE AND ACYLESTERASE IN THE ENZYMATIC DEGRADATION OF CEPHALOSPORINS

\section{Minoru Nishida, Yoshiko Yokota, Masao Okut, Yasuhiro Mine and Tadao Matsubara}

\author{
Research Laboratories, Fujisawa Pharmaceutical Co., Ltd., Osaka, Japan
}

(Received for publication August 28, 1967)

$m$-Bromophenylacetamidocephalosporanic acid( $m$-Br-PACA) was highly degraded by a strain (No. 11) of E. coli, but less degraded by a strain (No. 33) of Staph. aureus. $\alpha$-Phenylacetamidocephalosporanic acid ( $\alpha-\mathrm{Ph}-\mathrm{POCA})$ gave opposite results with these bacteria. A cephalosporin $\mathrm{C}$ derivative, $m-\mathrm{Cl}-$ PACA, was degraded by acylesterase as well as by $\beta$-lactamase with $E$. coli No. 11.

Since the degradation of cephalosporin $\mathrm{C}$ by Bacillus cereus was first reported by ABRAHAM and his co-workers, the microbial degradation of some other cephalosporins has been reported ${ }^{1,2,3)}$. Enzymes involved in degradation of cephalosporins are known to be the following: ${ }^{4)}$

(1) $\beta$-lactamases which hydrolyse the $\beta$-lactam ring such as penicillinase or cephalosporinase.

(2) Acylesterase which acts on the acetyl side-chain at position 3 of the cephalosporin nucleus.

(3) Amidase which splits the acyl side-chain at position 7 on the cephalosporin nucleus.

The inactivation of cephalosporins by pathogenic bacteria has been considered as mainly due to the enzymatic attack of $\beta$-lactamase; therefore little attention has been

Fig. 1. Structures of cephalosporins and penicillin

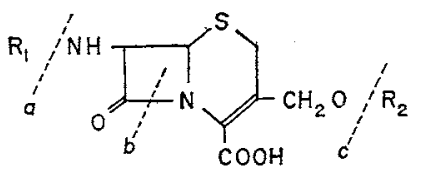

Cephalosporin C

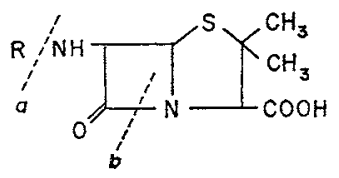

Penicillin

$a$ amidase or acylase

b $\beta$-lactamase

$c$ acyl esterase

\begin{tabular}{|c|c|c|}
\hline & $R_{1}$ & $\mathrm{R}_{2}$ \\
\hline $\begin{array}{l}\text { 7-Aminocephalosporanic } \\
\text { acid (7-ACA) }\end{array}$ & $\mathrm{H}-$ & $-\mathrm{COCH}_{3}$ \\
\hline $\begin{array}{l}\text { Aminoadipoylcephalo- } \\
\text { sporanic acid } \\
\text { (Cephalosporin C) }\end{array}$ & 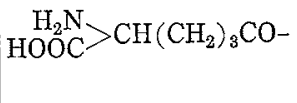 & 11 \\
\hline $\begin{array}{l}\text { m-Chlorophenylacetami- } \\
\text { docephalosporanic acid } \\
\text { (m-Cl-PACA) }\end{array}$ & $\mathrm{Cl}$ & $\prime \prime$ \\
\hline $\begin{array}{l}m \text {-Bromophenylacetami- } \\
\text { docephalosporanic acid } \\
\text { (m-Br-PACA) }\end{array}$ & $\mathrm{Br}$ & "I \\
\hline $\begin{array}{l}\alpha-\text { Phenylphenoxyacet- } \\
\text { amidocephalosporanic } \\
\text { acid }(\alpha-\mathrm{Ph}-\mathrm{POCA})\end{array}$ & & $\prime \prime$ \\
\hline
\end{tabular}


paid to the degradation of cephalosporins by other enzymes. The present paper shows that acylesterase plays an important role in the degradation of some cephalosporins by pathogenic bacteria, and that cephalosporins with different substituents at C-7 vary in their affinity for $\beta$-lactamase and acylesterase (Fig. 1).

\section{Methods and Materials}

(1) Organisms: Staphylococcus aureus No. 33 was isolated from a patient at the Institute for Medical Science. E. coli No. 11 was isolated from a patient at Kyoto Municipal Hospital.

(2) Incubation of cephalosporin derivatives with bacteria: The bacteria were grown in nutrient broth with shaking for 6 hours at $37^{\circ} \mathrm{C}$. After centrifugation, the bacterial cells were washed 2 times with KREBS-RINGER solution and suspended to give a cell count of $3 \times 10^{9} \mathrm{cells} / \mathrm{ml}$. Five $\mathrm{ml}$ of the bacterial suspension was added to the cephalosporin solution $(10 \mathrm{ml})$ at a concentration of $750 \mathrm{mcg} / \mathrm{ml}$, then incubated for varying times at $37^{\circ} \mathrm{C}$. The reaction mixture was centrifuged $(5,000 \times \mathrm{g}, 10 \mathrm{~min}$.) and mixed with an equal volume of $95 \%$ ethanol. The resulting mixture was used as the starting material for various determinations.

(3) Bioassay: Antibacterial activity was assayed by a disk method with Bacillus subtilis ATCC-6633 as the test organism.

(4) Determination of $\beta$-lactamase ${ }^{5}$ : A $5 \mathrm{ml}$ sample was added to $\mathrm{N} / 100 \mathrm{I}_{2}$ solution $(10 \mathrm{ml})$ in a stoppered flask and the mixture was titrated with $\mathrm{N} / 100 \mathrm{Na}_{2} \mathrm{~S}_{2} \mathrm{O}_{3}$ solution after standing for 15 minutes. The $\beta$-lactam ring of cephalosporin $\mathrm{C}$ derivatives is opened by $\beta$-lactamase activity, and an iodine uptake of 4 equivalents has been reported for this reaction.

(5) Autoradiography: Fifteen $\mathrm{ml}$ of a cell suspension $\left(1.2 \times 10^{10}\right.$ cells $\left./ \mathrm{ml}\right)$ of E. coli No. 11 was added to an equal volume of KREBS-RINGER solution which contained $10 \mathrm{mg}$ of

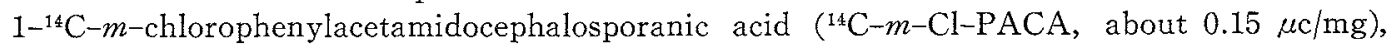
then incubated for 5 hours at $37^{\circ} \mathrm{C}$. The supernatant from centrifuging at $10,000 \times g$ for 5 minutes, was adjusted to $\mathrm{pH} 4.2$ and extracted 3 times with equal volumes of ethylacetate. The resulting aqueous layer was adjusted to $\mathrm{pH} 1$ and the same extraction was repeated.

Samples were applied to Toyo No. 51 paper, previously dipped in $0.05 \mathrm{M}$ phosphate buffer at $\mathrm{pH}$ 6.0. The chromatograms were developed with water-saturated 2-butanone by the ascending method. After drying in air, the paper chromatograms were wrapped in polystyrene ( $5 \mu$ in thickness), and exposed to Fuji X-ray film (Type 200) by the standard procedure.

(6) Fractionation of disrupted bacteria: This was carried out as described by SALTON ${ }^{6)}$. The bacterial suspensions ( $5 \mathrm{~g}$ wet weight/100 ml) in KREBS-RINGER solution were sonicated for 30 minutes (E. coli) or 90 minutes (Staph. aureus). The supernatant from $3,000 \times g$ for 10 minutes, or crude cell-free extract, was centrifuged $(5,000 \sim 9,000 \times g, 20 \mathrm{~min}$.) giving the cytoplasm fraction as supernatant. The precipitate from the second centrifugation was treated with trypsin and washed with Krers-Ringer solution. Then the cell wall fraction was obtained as supernatant by centrifugation at $2,000 \sim 3,000 \times \mathrm{g}$ for 10 minutes.

\section{Results}

(1) Enzymatic degradation of ${ }^{14} \mathrm{C}-m$-Cl-PACA by the clinically isolated strain of E. coli.

According to the procedure described above, the reaction mixture of ${ }^{14} \mathrm{C}-m-\mathrm{Cl}-$ PACA and the cell suspension of E. coli No. 11 was extracted with ethylacetate at $\mathrm{pH} 4.2$ and $\mathrm{pH}$ 1. The ethylacetate extract at $\mathrm{pH} 4.2$ gave three spots ( $\mathrm{Rf} 0.24,0.78,0.96$ ) 
Fig. 2. Autoradiograms

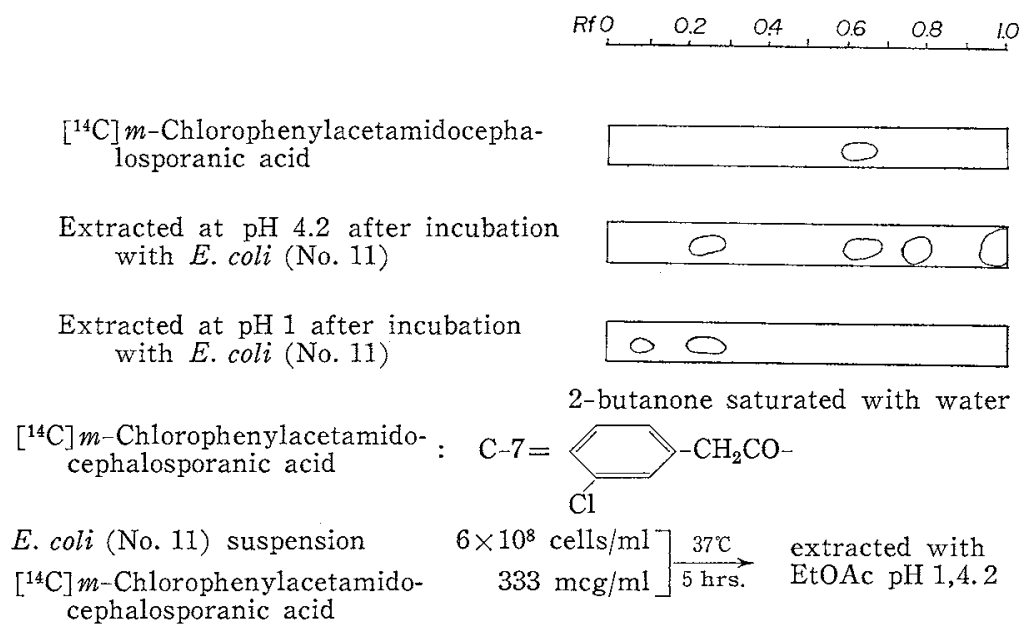

in addition to a control spot corresponding to ${ }^{14} \mathrm{C}-m$-Cl-PACA on the chromatograms. The extract at pH 1 gave spots with Rf 0.1 and 0.24 on the chromatogram (Fig. 2). $\mathrm{Rf}$ values of 0.24 and 0.96 correspond to those of authentic compounds of deacetylated ${ }^{14} \mathrm{C}-m-\mathrm{Cl}-\mathrm{PACA}$ and its lactone form. The substances with $\mathrm{Rf} 0 . \mathrm{I}$ and 0.78 were not identified, but these metabolites are probably derived from spliting of the lactam ring.

These results indicated that when ${ }^{14} \mathrm{C}-m$-Cl-PACA was incubated with a clinically isolated strain of $E$. coli, the cephalosporin was degraded by $\beta$-lactamase and also by an acylesterase.

(2) Correlation between inactivation and $\beta$-lactam hydrolysis of cephalosporin derivatives by the bacteria.

$m$-Bromophenylacetamidocephalosporanic acid ( $m$-Br-PACA) and $\alpha$-phenylphenoxyacetamidocephalosporanic acid ( $\alpha$-Ph-POCA) were incubated with cell suspensions of Staph. aureus No. 33 and $E$. coli No. 11, then assayed for residual antibacterial activity and extent of $\beta$-lactam hydrolysis. As shown in Table 1 , in the case of $m$-Br-PACA, the antibacterial activity showed $4.8 \%$ decrease, and the loss of $\beta$-lactam was $7.6 \%$, when incubated for 60 minutes with Staph. aureus No. 33. On the other hand, E. coli gave a $79.5 \%$ decrease in antibacterial activity and $56.6 \%$ of $\beta$-lactam hydrolysis.

Table 1. Relationship between inactivation and $\beta$-1actam hydrolysis of some cephalosporin $\mathrm{C}$ derivatives

\begin{tabular}{|c|c|c|c|c|c|c|}
\hline \multirow[b]{2}{*}{ Cephalosporins (C-7) } & \multicolumn{3}{|c|}{ Staph. aureus (No. 33) } & \multicolumn{3}{|c|}{ E. coli (No. 11) } \\
\hline & $\begin{array}{c}\mathrm{MIC} \\
\mathrm{mcg} / \mathrm{ml}\end{array}$ & $\begin{array}{l}\text { Decrease of } * \\
\text { antibacterial } \\
\text { activity }\end{array}$ & $\begin{array}{l}\text { B-lactam ** } \\
\text { hydrolysis }\end{array}$ & $\begin{array}{c}\mathrm{MCI} \\
\mathrm{mrg} / \mathrm{ml}\end{array}$ & $\begin{array}{l}\text { Decrease of * } \\
\text { antibacterial } \\
\text { activity }\end{array}$ & $\begin{array}{l}\beta \text {-lactam } * * \\
\text { hydrolysis }\end{array}$ \\
\hline & 6.25 & $4.8 \%$ & $7.5 \%$ & $>100$ & $79.5 \%$ & $56.6 \%$ \\
\hline$=\underbrace{\mathrm{O}}_{\mathrm{C}_{6} \mathrm{H}_{5}}$ & $>100$ & 36.1 & 0 & $>100$ & 4.0 & 0 \\
\hline
\end{tabular}

\footnotetext{
* Antibacterial activity was determined by a disk method.

** The iodometric method was used for determination of the $\beta$-lactam hydrolysis.
} 
Thus $m$-Br-PACA is highly sensitive to enzymatic degradation by a strain of $E$. coli (No. 11), but not by a strain of Staph. aureus (No. 33). However, the loss of antibacterial activity is similar to the extent of $\beta$-lactam hydrolysis in both $E$. coli No. $11(4.8 \%, 7.5 \%)$ and Staph. aureus No. $33(79.5 \%, 56.6 \%)$. These facts indicate that the degradation of $m$-Br-PACA by both bacteria is principally by $\beta$-lactamase.

Different results were obtained with $\alpha-\mathrm{Ph}$-POCA. The antibacterial activity showed a $36 \%$ decrease, while hydrolysis of the $\beta$-lactam ring was not detectable, when $\alpha$-Ph-POCA was incubated with Staph. aureus No. 33. With E. coli No. 11, the antibacterial activity of $\alpha$-Ph-POCA showed a $4 \%$ decrease and hydrolysis of the $\beta-$ lactam ring was negligible (Table 1). $\alpha$-Ph-POCA is highly degraded with Staph. aureus No. 33 but this degradation must be due to something other than $\beta$-lactamase.

(3) Degradation of $m-\mathrm{Br}-\mathrm{PACA}$ and $\alpha$-Ph-POCA by bacterial cell fractions.

Since it was found that degradation by bacterial suspensions gave different results. with $m$-Br-PACA and $\alpha$-Ph-POCA, the activity of bacterial cell fractions (crude cellfree extract, cytoplasm and cell wall) was compared with that of the bacterial suspensions to determine if permeability effects were operating (Tables 2, 3).

Table 2. Inactivation of $m$-bromophenylacetamidocephalosporanic acid by bacterial cell fractions

\begin{tabular}{l|r|r|r|r}
\hline \multirow{2}{*}{ Fractions } & \multicolumn{3}{|c}{ Inactivation \%* } \\
\cline { 2 - 5 } & $\begin{array}{r}\text { S. aureus } \\
\text { (No. 33) }\end{array}$ & \multicolumn{2}{|c}{$\begin{array}{c}\text { E. coll } \\
\text { (No. 11) }\end{array}$} \\
\cline { 2 - 5 } & $1 \mathrm{hr}$. & $3 \mathrm{hrs}$. & $1 \mathrm{hr}$. & $3 \mathrm{hrs.}$ \\
\hline Bacterial suspension & \multicolumn{1}{|c|}{0} & 18.6 & 100 & 100 \\
Crude cell-free extract & 15.0 & 34.1 & 70.3 & 99.4 \\
Cytoplasm & 9.1 & 25.5 & 72.3 & 99.2 \\
Wall & 3.1 & 3.9 & 2.8 & 5.4 \\
Crude culture & 10.6 & 22.5 & 11.6 & 48.0 \\
\hline
\end{tabular}

* The rate of inactivation of cephalosporin was determined by a disk method.
Table 3. Inactivation of $\alpha$-phenylphenoxyacetamidocephalosporanic acid by bacterial cell fractions

\begin{tabular}{|c|c|c|c|c|}
\hline \multirow{3}{*}{ Fractions } & \multicolumn{4}{|c|}{ Inactivation $\% *$} \\
\hline & \multicolumn{2}{|c|}{$\begin{array}{c}\text { S. aureus } \\
\text { (No. 33) }\end{array}$} & \multicolumn{2}{|c|}{$\begin{array}{l}\text { E. coli } \\
\text { (No. 11) }\end{array}$} \\
\hline & $1 \mathrm{hr}$. & $3 \mathrm{hrs}$. & $1 \mathrm{hr}$. & $3 \mathrm{hrs}$. \\
\hline Bacterial suspension & 87.2 & 95.4 & 20.3 & 29.4 \\
\hline Crude cell-free extract & 86.0 & 91.0 & 21.2 & 27.4 \\
\hline Cytoplasm & 77.1 & 84.8 & 2.7 & 19.7 \\
\hline Wall & 46.0 & 57.0 & 10.9 & 17.2 \\
\hline $\begin{array}{l}\text { Crude culture } \\
\text { supernatant }\end{array}$ & 62.6 & 69.0 & 10.9 & 18.7 \\
\hline
\end{tabular}

* The same method was used as in Table 2.

$m-\mathrm{Br}-\mathrm{PACA}$ was resistant to enzymatic attack of cell fractions derived from Staph. aureus No. 33, while this derivative was highly degraded by cell-free extract and cytoplasm derived from E. coli No. 11. These results with cell fractions were comparable to those with cell suspensions. With $\alpha$-Ph-POCA results were similar for cell suspensions and cell fractions with both E. coli No. 11 and Staph. aureus No. 33.

It may be concluded from these results that differences in the degradation of $m$ Br-PACA and $\alpha$-Ph-POCA by Staph. aureus No. 33 and E. coli No. 11 are not due to differences in permeability of the bacterial cells for the derivatives.

\section{Discussion}

A cephalosporin derivative, $m$-Br-PACA, is highly degraded by a clinically isolated strain (No. 11) of E. coli, but not by a clinically isolated strain (No. 33) of Staph. aureus. On the contrary, $\alpha-\mathrm{Ph}-\mathrm{POCA}$ is highly degraded by the same Staph. aureus, but not by the $E$. coli. These data are not consistent with a single enzyme (for example, $\beta$-lactamase) in both bacteria. It is evident in this experiment that the bacteria elaborate one or more 
$\beta$-lactamases plus at least one other enzyme (acylesterase) and that the activities of both enzymes differ considerably in the two strains. Also it seems reasonable to assume that the affinities of $m-\mathrm{Br}-\mathrm{PACA}$ and $\alpha-\mathrm{Ph}-$ POCA for both enzymes differ greatly, namely $m-\mathrm{Br}-\mathrm{PACA}$ has a high affinity for the $\beta$-lactamase from $E$. coli No. 11 , and $\alpha-\mathrm{Ph}-\mathrm{POCA}$ has a high affinity for the other enzymes (mainly, acylesterase) from Staph. aureus No. 33.

JEFFERY et al. ${ }^{7}$ ) found that cephalosporin derivatives were degraded by the acylesterase from citrus and the occurrence of the enzyme in marine bacteria was reported by Demain et al. ${ }^{8)}$. The role of this enzyme in pathogenic bacteria has not been studied. The present paper demonstrates that the acylesterase in some pathogenic bacteria may play an important role in the degradation of some cephalosporin derivatives (Table 4).

\section{Acknowledgement}

The authors wish to express their sincere thanks to Dr. OHARA, Director, and Dr. Kumada for guidance and encouragement, and Dr. Nakano and Dr. Takano for supplying cephalosporins.

\section{Bibliography}

1) SлöberG, B.; L. NAthonst-Westfert \& B. ÖRTEngRen : Enzymatic hydrolysis of some penicillins and cephalosporins by Escherichia coli acylase. Acta Chem. Scand. $21: 547 \sim 551,1967$

2) Bowman, F.E.; E. W. Knold \& M. White : Degradation of sodium cephalothin by cephalosporinase produced by Pseudomonas aeruginosa and Herellea sp. Antimicr. Agents \& Chemoth. 1964: $334 \sim 337,1965$

3) Stewart, G. T. \& R. J. Holt : Laboratory and clinical results with cephaloridine. Lancet 1964 $-2: 1305 \sim 1309,1964$

4) Poltock, M. R. : Enzymes destroying penicillin aud cephalosporin. Antimicr. Agents \& Chemoth. $1964: 292 \sim 301,1965$

5) Perret, C. J. : Iodometric assay of penicillinase. Nature $174: 1012 \sim 1013,1954$

6) Salton, M. R. J. : The bacterial cell walls. p. 42 91, 1964, Elsevier Publishing Co.

7) Jefferi, D. A.; E. P. Abraham \& G. G. F. Newton: Deacetylcephalosporin C. Biochem. J. 81 : 591 596, 1961

8) Demain, A. L.; R. B. Walton, J. F. Newkirk \& I. M. Mrluer : Microbial degradation of cephalosporin C. Nature $199: 909 \sim 910,1963$ 